\title{
Provisions of the Industrial Property Law Regarding Representative (Agent) Trademarks and Claims Based on Such Provisions
}

\section{Sınai Mülkiyet Kanununun Temsilci Markasına iliş̧̧in Hükümleri ve Bu Hükümlere Dayalı Talepler}

\section{Ismail Cem Soykan ${ }^{1}$ 우}

\begin{abstract}
This article has been written to review the provisions of Industrial Property Law Nr. 6769 regarding representative trademarks as well as the claims based on such provisions. The article first describes the common subjects of the provisions on representative trademarks, followed by the exceptional characteristics of the provisions. Afterwards, the common conditions required for implementation of provisions on representative trademarks are reviewed. Following the review of the common conditions, the claims based on provisions regarding representative trademarks are described. Finally, the issues regarding time-dependency of such claims and registration in bad faith are discussed.
\end{abstract}

\section{Keywords}

Mark, Trademark, Agent Trademark, Representative Trademark, Industrial Property Law, Trademark Law, Paris Convention for the Protection of Industrial Property

\section{Öz}

Bu makale, 6769 sayılı Sınai Mülkiyet Kanunu'nda yer alan temsilci markası hükümlerini ve anılan hükümlere dayalı talepleri incelemek amacıyla kaleme alınmıştır. Makalede öncelikle temsilci markası hükümlerinin ortak özneleri açıklanmış, takiben bu hükümlerin istisnai özelliklerine değinilmiştir. Bunlardan sonra, temsilci markası hükümlerinin uygulanması için varlığı gereken ortak şartlar incelenmiştir. Ortak şartlara ilişkin incelemenin ardından, temsilci markası hükümlerine dayalı talepler açıklanmıştır. Son olarak, bu taleplerin süreye bağlılıkları ve kötüniyetli tescil konuları ele alınmıştır.

\section{Anahtar Kelimeler}

Marka, Temsilci Markası, Vekil Markası, Sınai Mülkiyet Kanunu, Marka Hukuku, Sınai Mülkiyetin Himayesine İlişkin Paris İttihadı Mukavelenamesi, Paris Konvansiyonu

\footnotetext{
1 Corresponding Author: Ismail Cem Soykan (Res. Asst. Dr.), Istanbul University, Faculty of Law, Department of Commercial Law, Istanbul, Turkey. E-mail: icsoykan@istanbul.edu.tr ORCID: 0000-0003-2766-968X

To cite this article: Soykan, Ismail Cem: "Provisions of The Industrial Property Law Regarding Representative (Agent) Trademarks and Claims Based on Such Provisions", Annales de la Faculté de Droit d'Istanbul, 67, 2018, 73-107. https://doi.org/10.26650/annales.2018.67.0006 


\section{Provisions of the Industrial Property Law Regarding Representative (Agent) Trademarks and Claims Based on Such Provisions}

\section{Introduction}

Registration of an identical (or indistinguishably similar) trademark in the name of the agent or representative without the consent of the proprietor or without any justifiable ground as well as the rights of the proprietor in case of an application of such registration are regulated by IPL Art. 6/2, 10 and 25/1. The abovementioned IPL provisions are based on PC Art. $6^{\text {septies }}$ regulations ${ }^{1}$.

If the common conditions are fulfilled, the provisions regarding representative trademarks grants the following rights to the legal proprietor in parallel with the PC Art. $6^{\text {septies }}$ regulation ${ }^{2}$ :

1. to ensure rejection of the application and prevention of the registration by opposing the application - which is made without the consent of the legal proprietor and without justifiable ground - for the registration of the trademark in the name of the representative (IPL Art. 6/2),

2. to request invalidation of the trademark if it has been registered in the name of the representative (IPL Art. 25/1, 6/2),

3. to request transfer of the registration (trademark) to himself, also on the assumption that the trademarks has been registered in the name of the representative (IPL Art. 10) and

4. to request prohibition of the use of the trademark registered in the name of the representative (despite the registration) (IPL Art. 10)

This article aims to review and assess IPL provisions regarding the representative trademarks and the rights granted to the proprietor by these provisions. The outline of our article is as follows:

1 While expressed in DLPT period see Sabih Arkan, Marka Hukuku, Vol. I, Ankara 1997, p. 110-111; Sabih Arkan, "Yabancı Markaların Türkiye'de Korunması", Banka ve Ticaret Hukuku Dergisi, Vol. XX, Nr. 1, 1999, p. 9; Ünal Tekinalp, Fikrî Mülkiyet Hukuku, 5. Edition, İstanbul 2012, p. 421; Sami Karahan, Marka Hukukunda Hükümsüzlük Davaları, Konya n.d., p. 108; Hamdi Yasaman (Sıtkı Anlam Altay/Tolga Ayoğlu/Fülürya Yusufoğlu/Sinan Yüksel), Marka Hukuku 556 Sayılı KHK Şerhi, Vol. I, İstanbul 2004, p. 403; Hakan Karan/Mehmet Kılıç, Markaların Korunması 556 Sayılı KHK Şerhi ve İlgili Mevzuat, Ankara 2004, p. 204; Arslan Kaya, Marka Hukuku, İstanbul 2006, p. 150, fn. 173; Alper Tunga Ünal, Marka Hukukunda Tescil Engelleri, Unpublished Master's Thesis, Gazi University Institute of Social Sciences Department of Private Law, Ankara 2007, p. 63; Fatma Karaman, Marka Hukukunda Markanın Ülkeselliği İlkesi, Unpublished Master's Thesis, Marmara University Institute of Social Sciences Department of Law Sub Department of Private Law, İstanbul 2008, p. 118; Ali Paslı, Uluslararası Antlaşmaların Türk Marka Hukukunun Esasına İlişkin Etkileri, İstanbul 2014, p. 357-359; Orhan Sekmen, Markanın Hükümsüzlüğü ve Hukuki Sonuçları, 2. Edition, Ankara 2016, p. 175. On the other hand, we would like to note that Pasl $l$, who dedicated a thirty page section to the subject in his study -finding the source of the provisions regarding the representative trademarks in an international treaty must have been helpful-, is the author who analyzes representative trademarks in most detail as far as we have been able to identify (see Paslı, Etkiler, p. 357-387). For emergence of representative trademarks as an international issue of law and historical development of regulation in PC see Florian Bauer, Die Agentenmarke Rechtsfragen des internationalen Vertriebs von Markenwaren, Schriftenreihe zum gewerblichen Rechtsschutz Vol. 27, Köln Berlin Bonn München 1972, p. 8 ff.

2 See and cf. Paslı, Etkiler, p. 359. 
The subjects of the provisions on representative trademarks are common. Thus, for a reliable assessment, the meaning of the aforementioned "common subjects" must be specified in the first place.

The claims relating to the representative trademark, on the other hand, have some exceptional characteristics which are different from the general system of IPL. Indeed, the provisions regarding representative trademarks not only constitute an exception to the principle of territoriality and registration which are predominant in IPL, they also grant a right which is not included in the general system of IPL by granting the legal proprietor an authorization to request from the court to transfer the trademark registered in the name of the representative to himself (IPL Art. 10).

Finally, while each provision on representative trademarks grants the proprietor different opportunities, the conditions to be able to use the advantage of these provisions and make the abovementioned claims are the same. This means that there are "common conditions" to exercise the provisions on representative trademarks that apply for all the provisions and claims.

This requires an assessment of the abovementioned common subjects and common conditions as well as exceptional characteristics of the provisions on representative trademarks before reviewing the claims based on these provisions. Hence, we are going to identify and assess the common subjects, exceptional characteristics and common conditions for their exercise respectively and review the requests based on the abovementioned provisions afterwards.

\section{Common Subjects of Provisions on Representative Trademarks}

\section{A. Overview}

IPL Art. 6/2 specifies " A trademark application for the registration of an identical or indistinguishably similar trademark filed by a commercial agent or representative in his own name without the trademark proprietor's consent and without any justifiable ground shall be refused upon the trademark proprietor's opposition". Based on the reference thereof in IPL Art. 25/1, the existence of the conditions in this provision are also reasons for invalidation of a registered trademark.

IPL Art. 10 states "If an identical or indistinguishably similar trademark is registered in the name of the agent or representative without the consent of the trademark proprietor, unless the commercial agent or representative has a justifiable reason, the trademark proprietor may request from the court the prohibition of the use of his trademark and may also request the transfer of the said registration to himself.". 
It appears that the common subjects of IPL Art. 6/2 and 10 are "the trademark proprietor" and "the commercial agent or representative".

\section{B. Trademark Proprietor (Legal/Real Right Owner)}

"The trademark proprietor" referred to in IPL Art. 6/2 and 10 is the legal right owner of the sign (trademark) which the representative has registered or has applied for registration before $\mathrm{TPTO}^{3}$. The proprietor of a trademark is the person who originally formed and used it, meaning that he is the person that imagined and created (selected) the trademark and used it in connection with a good or service ${ }^{4}$.

It is highly important to state that the proprietorship (legal right ownership) of a trademark as in the meaning of IPL Art. 6/2 and 10 is not required to be based on an earlier domestic or foreign registration or registrations ${ }^{5}$. However the right owned in this sense has to be a "trademark right". Whether registered or not, the exercise of the provisions of representative trademarks cannot be requested based on any right other than a trademark right ${ }^{6}$.

It is not obligatory for the proprietorship of the trademark to be granted abroad for application of the provisions regarding representative trademarks ${ }^{7}$. This right might have also been obtained in Turkey ${ }^{8}$. While the states which are members of Paris Union will be encountered in the majority of incidents, it must be specified that foreign right ownership is not required to be obtained in a state which is a member of Paris Union to exercise the provisions of representative trademarks of IPL ${ }^{9}$. Similarly, the proprietorship of the trademark is not required to be obtained in the origin country of the goods ${ }^{10}$.

3 Indeed see Yasaman/Ayoğlu, Vol. I, p. 519, 520; Hamdi Yasaman/Sitkı Anlam Altay (Tolga Ayoğlu/Fülürya Yusufoğlu/ Sinan Yüksel), Marka Hukuku 556 Sayılı KHK Șerhi, Vol. II, İstanbul 2004, p. 696; Uğur Çolak, Türk Marka Hukuku, 4. Edition, İstanbul 2018, p. 330; Pasl,, Etkiler, p. 361, 362, 367, 373, 374, 378, 380, 381, 382, 383, 384, 385 and p. 379, fn. 352, p. 383, fn. 365; Hayrettin Çağlar, Marka Hukuku Temel Esaslar, 2. Edition, Ankara 2015, p. 72, 143.

4 See Tekinalp, p. 382; Yasaman, Vol. I, p. 183; Kaya, p. 186-187; for legal/real right ownership also see Çolak, p. 419-424.

5 Pasl, Etkiler, p. 361-362; Detlef von Schultz (and others), Kommentar zum Markenrecht, 2. Edition, Frankfurt am Main 2007, p. 241; in this regard see and cf. Tekinalp, p. 485; Sekmen, p. 176, 178; also see Arkan, Marka Vol. I, p. 111, fn. 180 where it is mentioned that registration or application for registration of the trademark in Turkey is not required to be able to oppose to the application of registration by the proprietor pursuant to IPL Art. $6 / 2$, in fact, PC Art. $6^{\text {septies }} / 1$ mentions a trademark owned in another country that is a member of Paris Union; finally see and cf. Bauer, p. 246.

6 von Schultz, p. 241; Georg Fuchs-Wissemann (and others), Markenrecht Vol. I Markengesetz und Markenrecht ausgewählter ausländischer Staaten, 2. Edition, Heidelberg 2009, p. 210; Çăglar, p. 72.

7 Paslı, Etkiler, p. 363-364, fn. 318; in terms of German law, in the same regard see Franz Hacker (Paul Ströbele/Irmgard Kirschneck), Markengesetz Kommentar, 8. Edition, Köln Berlin München 2006, p. 609, 612; von Schultz, p. 241; von Zumbusch, p. 426; Paul Lange, Marken- und Kennzeichenrecht, München 2006, p. 647; Fuchs-Wissemann, p. 207, 378; Astrid Meckel, "Agentenmarke", https://wirtschaftslexikon.gabler.de/definition/agentenmarke-31838/version-255389 (accessed on 17 July 2019), p. 1.

8 Indeed see Arkan, Yabancı Marka, p. 11, fn. 22 regarding that the provisions on representative trademark may be exercised when a non-registered trademark used in Turkey [DLPT Art. 8/3; IPL Art. 6/3] is requested to be registered (or is registered) in the name of the representative who also operates in Turkey without authorization, for example, the proprietor might request transfer of the registration in the name of the representative to himself based on 17 (IPL Art. 10); in terms of German Law in the same regard see for example von Schultz, p. 241.

9 In terms of German law in this regard see Hacker, p. 612; von Schultz, p. 241

10 Indeed see Bauer, p. 246; Hacker, p. 612. 
Whether or not the person who makes a request based on the provisions regarding representative trademarks (IPL Art. 6/2, 10, 25/1) is the proprietor of the trademark is to be determined by the applicable legislation of the state where the trademark right is claimed to be obtained ${ }^{11}$. However it is convenient to say that, in the majority of incidents, the proprietorship of the trademark will be based on an earlier registration

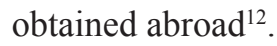

Within the scope of the abovementioned principles, the "proprietor of a trademark" is defined in doctrine as " a person who has acquired a property right on the trademark subject to application in a country which is a member of Paris Union other than Turkey before the application for registration in Turkey" in terms of application of provisions of PC and DLPT (IPL) regarding representative trademarks ${ }^{13}$. To emphasize again: while it is also possible that the proprietorship of the trademark to be obtained in Turkey, the provisions regarding representative trademarks of the referred PC and the IPL are based on a proprietorship obtained in a country other than Turkey (an in a Paris Union country as a principle even if not obligatory) and aim to protect such trademark proprietors ${ }^{14}$. This is because, those who obtain their proprietorship in Turkey are already protected by the provisions of IPL Art. 6/1, 6/3 and 25/1 against subsequent applications for registration and registrations of trademarks ${ }^{15}$.

Therefore, if the representative has registered the trademark in his name before TPTO, the proprietor (legal right owner) and the formal right owner of the trademark become different ${ }^{16}$. This is because although the trademark in question has been selected earlier by the proprietor (generally abroad) and has been used as a trademark and has even been registered in the name of the proprietor abroad, it is registered in the name of the "commercial agent or representative" before TPTO. Thus the agent or the representative is an "apparent" or a "formal" right owner in Turkey.

\section{The Concept of "Commercial Agent or Representative" in terms of Practice of Representative Trademarks}

After defining the meaning of the concept of "trademark proprietor" used in the provisions on representative trademark, it is now time to explain the concept of "commercial agent or representative" which is another subject of the abovementioned provisions.

11 Paslı, Etkiler, p. 362; Bauer, p. 246; Hacker, p. 612; von Schultz, p. 241.

12 Paslı, Etkiler, p. 361, fn. 313 and p. 363, fn. 318.

13 Paslı, Etkiler, p. 363.

14 Paslı, Etkiler, p. 362, 363, 364. The author states that DLPT Art. 8/2 (IPL Art. 6/2) is a special and exceptional regulation that provides protection to foreign trademarks (Paslı, Etkiler, p. 364-366) and that such interpretation of the provision is caused by the structure of the referred PC Art. $6^{\text {septies }}$ which emphasizes its exceptional characteristic, method and purpose of regulation of PC Art. $6^{\text {septies }}$ rather than the wording of DLPT (IPL) (Paslı, Etkiler, p. 366).

15 Paslı, Etkiler, p. 362; also see Sekmen, p. 178 and Yasaman/Ayoğlu, Vol. I, p. 518 who mention "the trademark proprietor whose trademark is not registered in Turkey".

16 Yasaman/Ayoğlu, Vol. I, p. 519; Karaman, p. 121-122; Paslı, Etkiler, p. 381; Bauer, p. 179. 
Firstly, it must be noted that to exercise the provisions of IPL regarding representative trademarks (IPL Art. 6/2, 10, 25/1), the trademark proprietor and the person who has registered or applied for registration of the trademark in his name before TPTO must have a relationship which concerns the use of the trademark, distribution of the goods branded with the trademark or delivery of service or services under such trademark ${ }^{17}$. The relationship between the proprietor and the person who wants to register or has registered the trademark in his name is defined as "commercial agency" or "commercial representation" in IPL - as in DLPT 18 .

Today it is unanimously accepted in Turkish doctrine that the expressions "commercial agent or representative" used in the provisions on representative trademarks shall not be limited to the commercial agent or (commercial) representative in the technical legal meaning specified in TCO Art. 547 ff. but shall be interpreted in a broad sense and any person who is authorized to use the trademark in Turkey (for example to sell the goods branded with the trademark or provide service or services under the trademark on behalf of the proprietor or himself) pursuant to any relationship such as attorney contract, exclusive distributorship agreement, labor contract, license agreement, franchise agreement, agency contract, brokerage contract, distributorship or dealership agreement shall be deemed as "representative" in terms of exercise of IPL Art. 6/2 and 10, whether or not granted the power to represent the proprietor in technical legal meaning ${ }^{19,20}$. The same applies for the practice by TPTO ${ }^{21}$. Thus, we use the term "representative" to imply the abovementioned meaning in this study.

17 We have adapted this assessment made by Arkan in terms of DLPT Art. 8/2 to IPL (see and cf. Arkan, Marka Vol. I, p. 111; Kaya, p. 150; Pasli, Etkiler, p. 367).

18 Kaya, p. 150.

19 Arkan, Marka Vol. I, p. 111; Arkan, Yabancı Marka, p. 11; Tekinalp, p. 421, 485; Yasaman, Vol. I, p. 403; Yasaman/ Ayoğlu, Vol. I, p. 519, 520; Yasaman/Altay, Vol. II, p. 696; Karahan, p. 108-109; Kaya, p. 150; Karan/Kılıç, p. 205; Ünal, p. 64; Karaman, p. 120, 122, 123; Paslı, Etkiler, p. 366-368; Çağlar, p. 71-72; Çolak, p. 330-331; Erdal Noyan/ İlhami Güneş, Marka Hukuku, 5. Edition, Ankara 2015, p. 158; Sekmen, p. 176-177; also see the decisions of Court of Cassation referred to in Sekmen, p. 177, fn. 556; finally see Karan/Kılıç, p. 205; Kaya, p. 150 regarding that this relationship may be based on a unilaterally granted power of representation.

20 For a similar example in German doctrine see Bauer, p. 241-246; Wolfgang Berlit, Markenrecht, 11. Auflage, München 2019, p. 142; Hacker, p. 610; von Schultz, p. 241-242; Lange, p. 647-648; Fuchs-Wissemann, p. 207-208. Also see Bauer, p. 246 regarding that the term "representative" must be construed in economic terms and that all the exporters integrated on the basis of rights and liabilities beyond an ordinary purchase-sale relationship as an "economic representative" of the proprietor in his distribution system shall be considered "representative" in German law; see von Schultz, p. 242 who (with reference to a decision of Hamburg OLG) emphasizes the relationship between the parties shall exceed an ordinary exchange of goods, imposing them to protect the interests of one another and the bond of interest between the parties shall be understood from the contractual relation; in this regard also see Hacker, p. 610; Lange, p. 647-648; Fuchs-Wissemann, p. 207-208.

21 The following statement on p. 126 of TPI's (TPTO's) 2015 Trademark Examination Guideline clearly shows TPTO's practice in such regard [for full text of the manual see https://www.turkpatent.gov.tr/TURKPATENT/resources/temp/ F9E4CFAF-A7AE-4FEA-8BCC-DA8B5C7DAB00.pdf (accessed on 5 July 2019)] "...the proprietor and the person applying for trademark must have a business relation which grants the power to use the trademark in Turkey on behalf of the legal right owner, to put the trademark in the market and to distribute. Such business relation and the concept of agent and representative mentioned in the provision must be construed in a broad sense to include any economic relation which is legal-commercial or only commercial. The business relations between the parties are generally based on a contract that authorizes the representative to use the trademark and in this case the provisions of the contract become crucial. The primary types of contracts that may be considered as a relation of an agent or representative are contracts of agency, exclusive distributorship, franchising, licensing, partnership, attorney, labor, dealership and import.". 
Nevertheless the relationship between the proprietor and the representative must be subject to a certain consistency and commitment ${ }^{22}$. A simple/ordinary sales engagement based on a discrete sales contract does not qualify the purchaser as a "representative" 23 . Hence for example, a person who purchases a good branded with the trademark from abroad to deliver into Turkey via direct or parallel import and sell the goods cannot be deemed a "representative" within the scope of IPL Art. 6/2 and 10, thus provisions of IPL on representative trademarks (IPL Art. 6/2, 10, 25/1) cannot be applied under such assumptions ${ }^{24}$.

Therefore if a person cannot be qualified as a representative in the context of IPL Art. 6/2 and 10, meaning that if they do not have a relationship with the proprietor that grants the authority to use the trademark as exemplified above, the registration application of such a person cannot be opposed based on IPL Art. 6/2 25 . If the trademark has been registered in his name, the trademark proprietor cannot ensure invalidity of the registration based on IPL Art. 25/1 and 6/2 or cannot request assignment of the trademark in his favor pursuant to IPL Art. 10 and cannot prohibit the use of the trademark by the registration holder within the scope of IPL Art. 10. In such a case, the proprietor, provided that the conditions are met, can apply to means other than the provisions on representative trademarks (IPL Art. 6/2, 10, 25/1). Thus, if the required conditions are fulfilled, the proprietor can demand the rejection of a registration application or the invalidity of the trademark based on other regulations of IPL (such as IPL Art. 6/1, 6/3, 6/4 or 6/9) ${ }^{26}$.

Arkan claims that interpreting the requirement of being a party to the contract that authorizes the use of the trademark, as exemplified above, in a strict sense would cause IPL Art. 6/2 (DPLT Art. 8/2) to be easily bypassed; thus it is required to consider that a trademark subject to application not only in the name of the agent or exclusive distributor that is a party to the contract but also in the name of their commercial representatives or employees within the scope of IPL Art. 6/2 (DPLT Art. 8/2) ${ }^{27}$. In parallel, Pasl $\iota$ discusses that any person who uses the trademark by a written, verbal or de facto application within the scope of a mutual definite relation based on the authorization by the proprietor shall be considered a "representative" through a broad

22 Arkan, Yabanc1 Marka, p. 11; Paslı, Etkiler, p. 368.

23 Arkan, Yabanc1 Marka, p. 11; Pasl,, Etkiler, p. 368, fn. 330; in this regard particularly see Bauer, p. 242-243; Hacker, p. 610; von Schultz, p. 241-242.

24 Pasl, Etkiler, p. 368.

25 Arkan, Marka Vol. I, p. 111-112; Karahan, p. 109; Kaya, p. 150-151, fn. 174; Paslı, Etkiler, p. 368; also see Arkan, Yabanc1 Marka, p. 10-11.

26 Arkan, Marka Vol. I, p. 112, fn. 181; Arkan, Yabancı Marka, p. 14 ff.; Kaya, p. 150-151, fn. 174; Ünal, p. 64; Paslı, Etkiler, p. 368-370 also and in particular see Paslı, Etkiler, p. 368-370, fn. 331 and TEG, p. 124.

27 Arkan, Marka Vol. I, p. 112; Arkan, Yabancı Marka, p. 11; in the same regard see Sekmen, p. 177; also see von Schultz, p. 242; von Zumbusch, p. 427; Hacker, p. 610-611, 835; Lange, p. 649; Fuchs-Wissemann, p. 208-209, 380 regarding that the "straw men" behind the representative who act on orders and instructions of the representative shall also be included in the extent of the provisions of representative trademarks. 
interpretation that will prevent an unfair advantage of the principle of territoriality; he claims that any application of registration by this person in his name as well as by the persons who are directly connected in their own names had better be included within the scope of IPL Art. 6/2 (DPLT Art. 8/2) by lifting the veil of incorporation ${ }^{28}$.

TPTO appears to adopt an interpretation in a broad sense, considering the statements in the TEG regarding DLPT Art. 8/2 (IPL Art. 6/2) which are as follows; "...it is not required for the application to be made in the name of the agent or representative for enforcement of the article, but when there is sufficient proof that any application made upon the request or instructions of the agent or the representative and made by the spouse, children of the agent or representative or the executives of a company owned by the agent or the representative who shares the same financial interest, these applications shall be evaluated within this scope." 29 , "The parties of the contract shall be interpreted in a broad sense when the business relation is based on a contract. ... it shall be considered that there is a business relation not only between the parties of the contract, but also between their partners, representatives and employees. " 30 .

However it must be noted that another view in the doctrine is that an interpretation IPL Art. 6/2 (DPLT Art. 8/2) in such a broad sense would not serve to prevent a bypassing of the provision since a representative who wants to avoid the prohibition would apply for registration of the trademark in the name of a person who is not related; therefore, this view discusses the idea that the provision should not be expanded as much to include the bad faith of the representative and that the "party" should be considered as any person who is a party to the contract with the proprietor $^{31}$.

A relationship as per above between the proprietor and the "representative" is required and sufficient for exercise of the provisions regarding representative trademarks ${ }^{32}$. The provisions of representative trademarks shall apply even if such relations have not been exercised or have been terminated afterwards ${ }^{33}$. Therefore,

28 Pasl, Etkiler, p. 367. The author states that if a person related to the representative (such as the spouse, children or any other person who shares the same economic interests with the representative) applies for the registration of the trademark in his name and the concerned authorities (TPTO) identify such a relation, the provisions on representative trademarks shall apply, as a rule. In order for the provisions on representative trademarks not to be applied in such a case, the applicants must prove that they are not under the influence of the representative and not related or connected to the representative or the proprietor (Paslı, Etkiler, p. 367, fn. 328).

29 TEG, p. 125.

30 TEG, p. 126

31 Karahan, p. 108-109, fn. 2.

32 Paslı, Etkiler, p. 372.

33 Pasl, Etkiler, p. 372, 358; also see Yasaman/Ayoğlu, Vol. I, p. 520; Bauer, p. 247-248; Berlit, p. 160; Fuchs-Wissemann, p. 209; for a different view see Arkan, Yabanc1 Marka, p. 10 who claims that the wording of PC Art. $6^{\text {septies }}$ is not broad enough to be concluded to cover a representative whose authority has expired and that it is not possible to mention a "representative" after termination of the relation between the parties [it should be added that the study also includes the following statements, referring to the foreign doctrine "However it is stated that accepting this formal interpretation would not serve to the requirements of the practice and the registration of the trademark by the former representative who $i$. still interested in the trademark even after expiration of the representation relation in his name and use of the trademark 
what matters for application of the provisions on representative trademarks is for the "representative" to hold such position for once ${ }^{34}$. Hence, the relations between the proprietor and the representative are not required to be maintained when the application for registration of the trademark is opposed (IPL Art. 6/2) or prohibition of the use of the registered trademark (IPL Art. 10) or invalidity (IPL Art. 25/1, 6/2) or transfer (IPL Art. 10) of the trademark is claimed ${ }^{35}$. In fact, the doctrine highlights that the necessity for protection of the proprietor arises when the contractual relation between the proprietor and the representative ends ${ }^{36}$.

\section{Exceptional Characteristics of the Provisions Regarding Representative Trademarks}

There are three exceptional characteristics of the provisions on representative trademarks. These are: (i) precedence of the legal/real right owner (proprietor) over formal right owner which is an exception to the principle of registration (IPL Art. 10; DLPT Art. 11), (ii) ability to transfer the trademark though a court decision (IPL Art. 10; DLPT Art. 17) and (iii) being provided for as an exception to the principle of

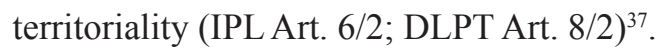

An exception to the principle of registration is introduced in IPL Art. 10. In case common conditions ${ }^{38}$ exist, this provision enables the proprietor to apply to the court and have the use of the trademark by the formal right owner prohibited ${ }^{39}$. Therefore if the court finds such application justified, the representative cannot use the trademark even if it is registered in his name before TPTO.

by the former representative for goods that are not produced by the foreign trademark proprietor is included in the scope of prohibition." (Arkan, Yabancı Marka, p. 10)]; also see Çağlar, p. 72 who states that the provision on application/ registration in bad faith [DLPT Art. 35/1; IPL Art. 6/9, 25/1] instead of provisions on representative trademarks shall apply after the termination of the relation between the proprietor and the representative; see von Schultz, p. 244 regarding that the ground for invalidity in MarkenG $\S 11$ in German law shall apply only if the registration application is made while the relation between the parties continues; but for the applications made after the termination of the contract the proprietor shall request invalidity on the ground of registration in bad faith and on other grounds; in similar regard see Hacker, $p$. 611; Lange, p. 648.

34 Paslı, Etkiler, p. 372.

35 In particular see Pasl, Etkiler, p. 372-373, fn. 335. Therefore, it is not possible to agree with the following statements in (TEG, p. 126) "The commencement date of the contract must be earlier than the date of application of trademark registration made by the agent or representative to Turkish Patent Institute. Negotiations made between the applicant and the trademark proprietor who opposes to the application on a date after the application regarding representation of the trademark and unilateral initiatives by the applicant to be the representative of the trademark in question shall not have any importance in terms of examination of the opposition and shall not affect the decision. If the former representative applies for registration of the trademark after termination of the relation of representation, the opposition of the privileged trademark proprietor shall not be assessed within the scope of article $8 / 2$ since the business relation is terminated. (Excluding the reasonable time period after termination in which the effects of the contract remain)" (Pasli, Etkiler, p. 372, fn. 335).

36 Yasaman/Ayoğlu, Vol. I, p. 520; Karaman, p. 122; also see von Schultz, p. 240 regarding that the representative trademarks registered during the relation between the parties allow "disloyal" representatives to put pressure on the proprietor for continuation of the relation in case of termination of the contractual relation and the provisions regarding the representative trademarks are regulations against such cases; similarly see Hacker, p. 608.

37 Paslı, Etkiler, p. 381, fn. 359.

38 For remarks on common conditions see IV.

39 For detailed explanation about the subject see V, C. 
Also subject to the existence of the common conditions, another exception introduced by IPL Art. 10 is that it allows the proprietor to have the registration in the name of the representative (trademark) transferred in his favor through court decision $^{40}$. Indeed, it is impossible as a rule in Turkish trademark law for a person who claims to be the proprietor of a registered trademark to have the registration transferred to himself through filing a case ${ }^{41}$. IPL Art. 10 is an exception to this rule.

The third and a highly important exceptional characteristic of the provisions on representative trademarks is that these provisions (IPL Art. 6/2 and 10) are exceptions to the principle of territoriality of protection of trademarks which is predominant in IPL. The principle of territoriality in terms of trademark law is that each state allows trademark protection within its country, provided that the meritorious and formal requirements in its law are fulfilled, which in such regard means that each state grants the authority to take legal actions in its country to the persons who are right owners within the scope of its own law whose rights are violated by infringements in its own country ${ }^{42}$. Pursuant to such a principle, the trademark right is limited to the territory of the country where it is registered and the rights and protection provided by registration of a trademark is limited to the country where the trademark is registered ${ }^{43}$.

However the provisions on representative trademarks (IPL Art. 6/2, 10, 25/1) grant those who have not acquired their proprietorship in Turkey and who are not considered as right owners under Turkish legislation the rights to prevent a registration through opposing the registration application of a trademark before TPTO in Turkey (IPL Art. $6 / 2$ ), to have the use of the trademark rights arising from a completed registration prohibited and have the registration (trademark) transferred in his name (IPL Art. 10) or claim invalidity of a registered trademark (IPL Art. 6/2, 25/1). This becomes an exception to the principle of territoriality in terms of "each state grants the authority to take legal actions in its country to the persons who are rightful owners within the scope of its own law whose rights are violated by infringements in its own country" 44 . There is no uncertainty in the doctrine that the protection and the opportunities provided by the provisions on representative trademarks to the proprietor are exceptions to the principle of territoriality ${ }^{45}$.

40 For detailed explanation about the subject see V, D.

41 Paslı, Etkiler, p. 378.

42 Tekinalp, p. 431. For principle of territoriality also see Arkan, Yabancı Marka, p. 5; Tekinalp, p. 431-432; Karaman, p. 61-65; Pasli, Etkiler, p. 177 ff. and as a whole Karaman, passim.

43 Tekinalp, p. 432.

44 Tekinalp, p. 432; from this aspect see again Karaman, p. 61-65.

45 Indeed see Arkan, Yabancı Marka, p. 9; Yasaman/Ayoğlu, Vol. I, p. 10, 520; Karaman, p. 119, 121; Paslı, Etkiler, p. 357, 358, 360-361, 363, 364, 366, 367, 382 and p. 362, fn. 316; also see Bauer, p. 255; Hacker, p. 608. 


\section{Common Conditions for Application of Provisions on Representative Trademarks}

\section{A. Overview}

The provisions on representative trademarks protect a common interest. As can be understood from the remarks such as "The representative trademark, ... is a trademark which a person who has the authority to use such trademark within the framework of a business relation engaged with the trademark proprietor in compliance with the law tries to acquire through an application in his own name after termination of ${ }^{46}$ or during such relation, in the country where he holds the authority to use the trademark or in another one or several countries within Paris Union by abusing his position and knowledge obtained in parallel with the authority to use the trademark" in the doctrine ${ }^{47}$, such interest is prevention of seizure and use of a trademark created and used by the proprietor which has been extended via "representatives" in time by these "representatives" in bad faith ${ }^{48}$. From this aspect, the provisions on representative trademarks, as will be mentioned below ${ }^{49}$, aim to prevent any problem that may be caused by the proprietor and formal right owner being different parties ${ }^{50}$.

It is indeed a fact that the foreigners consent to registration of their trademarks before TPTO in the name of and/or use hereof by their "representatives" as well as their exclusive distributors and agents in order to protect their trademarks against third parties efficiently in Turkey ${ }^{51}$.

Hence, in parallel with the same interest they share, the conditions of application of the provisions on representative trademarks are common. In this context, the following conditions are required to exist at the same time in order for application of provisions on representative trademarks (IPL Art. 6/2, 10, 25/1),

1. The trademark registered or applied for registration in the name of the representative must be identical or indistinguishably similar to the trademark of the proprietor,

2. Such registration or application must be made without authorization of the trademark proprietor and

3. The representative must not have any justifiable grounds.

46 On this subject, see II, C.

47 Paslı, Etkiler, p. 366.

48 Paslı, Etkiler, p. 361.

49 See V, C.

50 Pasl, Etkiler, p. 381.

51 Yasaman/Ayoğlu, Vol. I, p. 520; cf. Karan/Kılıç, p. 205. An opinion in the doctrine expresses that the parties are engaged in a "fiducia" in such cases and emphasizes that the necessity for protection of the proprietor arises upon the termination of the contractual relation between the proprietor and the representative, as we mentioned earlier (Yasaman/Ayoğlu, Vol. I, p. 520; Karaman, p. 122; also see Pasli, Etkiler, p. 360-361). 
However before analyzing these three common conditions, we would like to point out the following:

First of all, the provisions on representative trademarks apply to both the service marks and the trade marks ${ }^{52}$. Therefore whether the mark in question is a service mark or a trademark is not important in terms of exercise of the rights granted to the proprietor by IPL.

Secondly, it is not required for the trademark to be well-known for the proprietor to exercise the protection granted by the provisions on representative trademarks. The provisions on representative trademarks enables the proprietor to bypass the principle of territoriality even if his trademark is not well-known ${ }^{53}$.

Thirdly, even if the conditions of application of the provisions on representative trademarks are common, the authority to exercise such provisions is not always the same $^{54}$. If there is a registered trademark, the requests for prohibition and transfer of this trademark (IPL Art. 10) or its invalidity (IPL Art. 25/1, 6/2) shall be sent to the court. However if there is an application for registration (IPL Art. 6/2), the proprietor opposes to the application before TPTO and TPTO shall be the authority to make a decision on the opposition in question.

Following this overview, we may now start reviewing the common conditions for application of the provisions of representative trademarks.

\section{B. The Trademark Registered or Subject to Application for Registration Being Identical or Undistinguishably Similar to the Trademark of the Proprietor}

The provisions of IPL regarding representative trademarks only mention the trademark registered or subject to application for registration before TPTO as "identical or undistinguishably similar to the trademark of the proprietor" (IPL Art. $6 / 2,10)$. However despite the strict sense in the wording of these provisions it must be accepted that the protection granted by the provisions regarding representative trademarks is to the extent specified in IPL Art. 6/1. That is to say:

TEG uses the following statements regarding DLPT Art. 8/2 (IPL Art. 6/2) "The trademark for which the agent or the representative applies for registration regarding the identical or the same type of goods or services can be either identical or undistinguishably similar to the trademark owned by the trademark proprietor. Moreover the proprietor can oppose to the applications for registration for trademarks

52 Paslı, Etkiler, p. 374. For detailed explanation about trade and service marks see Kaya, p. 50-52.

53 Indeed see Paslı, Etkiler, p. 364.

54 Paslı, Etkiler, p. 380, fn. 356. 
of goods and services that are identical or undistinguishably similar to the goods and services of his trademark" ${ }^{\prime \prime 5}$. Therefore, in practice, TPTO considers the scope of the protection granted by IPL Art. 6/2 as identical to that of IPL Art. 6/1.

Similar to the broad approach adopted by TPTO, the doctrine also specifies that it would be accurate to consider the scope of the protection granted to the abroad obtained trademark right - which enables the proprietor to oppose the application of registration submitted to TPTO - as parallel to DLPT Art. 8/1 and 9/1 (IPL Art. 6/1 and 7/2), thus DLPT Art. 8/2 (IPL Art. 6/2) can apply when the trademark subject to the application of registration by the representative is identical or similar in terms of both the sign and the goods or services of the trademark of the proprietor ${ }^{56}$.

We believe such statement to be accurate. Therefore the terms "identical or undistinguishably similar" in IPL Art. 6/2 and 10 should be interpreted as in IPL Art. 6/1. Considering their purpose, interpretation of IPL Art. 6/2 and 10 in a strict sense would deprive the proprietor of a functional protection and would enable representatives to avoid application of the said provisions ${ }^{57}$.

However - while opposite opinions also exist in the doctrine ${ }^{58}$ it would not be correct to expand the protection granted to the proprietor by provisions on representative trademarks (IPL Art. 6/2, 10, 25/1) to include "different goods and services" 59 . Accepting otherwise would mean protection of non-well-known trademarks as if they were well-known against representatives and expansion of the protection exclusively granted to the well-known trademarks by IPL Art. 6/5 to all representative trademarks ${ }^{60}$.

55 TEG, p. 126.

56 Paslı, Etkiler, p. 373; Çağlar, p. 72; in terms of DLPT period also see and cf. Çolak, p. 909; Ünal, p. 64. We must add that while Arkan states in a study that within DLPT Art. 8/2 (IPL Art. 6/2) an application for registration for an "identical" trademark owned by somebody else for the same type of good or service is in question (Arkan, Marka Vol. I, p. 111, fn. 179), he also states in another one of his studies that the proprietor should be able to oppose the registration of an "identical or undistinguishably similar" trademark in the name of the representative, on the condition of regarding the same type of goods (Arkan, Yabanc1 Marka, p. 12; in this regard also see Paslı, Etkiler, p. 373, fn. 337). Also see Kaya, p. 152; Sekmen, p. 178 regarding the types of the trademarks which the proprietor can object to the registration based on IPL Art. 6/2 (DLPT Art. 8/2)

57 Paslı, Etkiler, p. 373. For the view in German law regarding the concept of representative trademarks not being limited to the trademarks that are "identical" to the trademark of the proprietor but also include the trademarks that are undistinguishably similar as in the meaning of MarkenG § 9/1-Nr. 2 see von Schultz, p. 241, 243; Hacker, p. 611-612; also see von Schultz, p. 240; Lange, p. 648; Fuchs-Wissemann, p. 210.

58 With the following statements, Yasaman accepts that under certain conditions a protection which is at the same degree with the protection granted for a well-known trademark may be granted to the proprietor "The registration of the trademark by the agent or the representative for different goods and services may not be justified under certain circumstances. This may contradict with the rules of unfair competition. Taking unfair advantage of business products of another person may not be justified. In this context, if the registration by the commercial agent or representative of the trademark of the person whom they represent for different goods and services aims taking unfair advantage of the trademark or taking advantage of its distinguishing power and reputation, it should be possible to oppose to the application of registration for the trademark." (Yasaman, Vol. I, p. 404; following Yasaman see Ünal, p. 64; Karaman, p. 120 in the same regard).

59 Indeed see Paslı, Etkiler, p. 373-374; particularly see Pasl,, Etkiler, p. 374, fn. 339; also see and cf. Arkan, Marka Vol. I, p. 111, fn. 179 and Karan/Kılıç, p. 204.

60 Pasl, Etkiler, p. 374. 
Hence if a trademark applied for registration or already registered in the name of the representative before TPTO is identical or similar to the trademark of the proprietor in terms of both the sign and the goods or services ${ }^{61}$ and if this situation causes a likelihood of confusion -including the relation possibility by the public- between them (IPL Art. 6/1), the provisions of the representative trademarks (IPL Art. 6/2, 10, 25/1) may apply. This is the first common condition required for application of the provisions on representative trademarks.

Therefore if the following conditions to be analyzed below also exist, the proprietor has the opportunities to oppose the registration application before TPTO (IPL Art. $6 / 2$ ), to request the prohibition of use or assignment in his favor of the trademark registered by such means (IPL Art. 10) or to claim invalidity of the trademark (IPL Art. 25/1, 6/2) if it causes a likelihood of confusion - including the relation possibility by the public - with his trademark because of the identity or similarity of the signs and identity or similarity of the goods or services that it covers.

\section{Registration or Application for Registration Being Made Without Authorization of the Proprietor}

The second common condition required for application of the provisions on representative trademarks is making application of registration or registration of the trademark without the consent of the proprietor.

It must be noted in the first place that the "authorization" mentioned hereby is not the authorization granted to the representative within the framework of the relation between the representative and the proprietor, but the authorization "for registration of the trademark in the name of the representative before TPTO", meaning the authorization "for registration" 62 .

On the other hand although the term "authorization" is used in IPL Art. 6/2 and 10, in fact the real intention here is to mention the "consent of the proprietor to registration of the trademark in the name of the representative" $"$. Thus if the proprietor approves the registration in the name of the representative later, even if permission had not been requested from him in the first place, the registration now becomes subject to consent and "authorized" within the meaning in IPL Art. 6/2 and $10^{64}$.

\footnotetext{
61 Regarding similarity of goods and services see Arkan, Marka Vol. I, p. 102-103; Tekinalp, p. 442; Yasaman, Vol. I, p. 397-399; Karan/Kılıc, p. 200-201; Kaya, p. 148-149; Çağlar, p. 66-71; Çolak, p. 210-225; Sevilay Uzunallı, "Marka Hukukunda Malların ve/veya Hizmetlerin Benzerliğinin Tespiti Sorunu”, Prof. Dr. Hamdi Yasaman'a Armağan, İstanbul 2017, passim; regarding good (product) similarity in particular see Ali Paslı, Marka Hukukunda Ürün Benzerliği, İstanbul 2018, passim.

62 Paslı, Etkiler, p. 375; also see Yasaman/Ayoğlu, Vol. I, p. 518.

63 See Bauer, p. 247; Arkan, Yabancı Marka, p. 12, fn. 23; Hacker, p. 613; Fuchs-Wissemann, p. 211.

64 TEG, p. 127.
} 
The authorization or consent specified in IPL Art. 6/2 and 10 is not subject to any form requirement ${ }^{65}$. Therefore, such authorization or consent does not have to be based on a written contract ${ }^{66}$. Likewise, such authorization or consent does not necessarily have to be "explicit". The authorization or consent to be granted by the proprietor to the representative for registration of the trademark in his name can also be "implied (implicit)" representative, non-objection by the proprietor even if he is aware of the circumstances and maintaining of the relation between the parties over the formal right ownership of the representative indicate authorization or consent of the proprietor ${ }^{68}$. This means that the authorization and consent may be concluded from the actual incidents ${ }^{69}$.

As a result of the authorization or consent requirement being aimed at "registration", it cannot be construed from the proprietor's acquiescence to the use of the trademark by the representative or the image portrayed by the representative as the "proprietor of the trademark" in the market that the proprietor permitted or approved the registration of the trademark in the name of the representative $\mathrm{e}^{70}$.

On the other hand such authorization or consent, which is based on a more thorough market knowledge that the representative possesses and his ability to take faster and more efficient precautions for protection of the trademark, can be revoked at any time by the proprietor, even if the relations between the parties are still effective ${ }^{71}$. If the proprietor revokes such authorization on justified legal grounds, now he cannot only request prohibition of the use of the registered trademark and transfer of the trademark in his name (IPL Art. 10) but also have the trademark invalidated if he wants (IPL Art. 25/1, 6/2) ${ }^{72}$.

For oppositions based on IPL Art. 6/2 in trademark registration, it is assumed as a rule that the proprietor does not have consent for the registration and the burden

65 See Fuchs-Wissemann, p. 211

66 Kaya, p. 151; Paslı, Etkiler, p. 375-376, fn. 343.

67 TEG, p. 127; Arkan, Yabancı Marka, p. 12, fn. 23; Karan/Kılıç, p. 205; Karahan, p. 109; Kaya, p. 151; Karaman, p. 124; Paslı, Etkiler, p. 375; Noyan/Güneş, p. 663; Sekmen, p. 177; Bauer, p. 247; von Schultz, p. 242; Fuchs-Wissemann, p. 211.

68 Paslı, Etkiler, p. 375-376, fn. 343; also see Bauer, p. 247.

69 Karan/Kulıc, p. 205; Kaya, p. 151. See Bauer, p. 246-247; Hacker, p. 613 regarding that the authorization may be concluded based on actual incidents if the proprietor demands the representative to take measures for protecting the trademark; also see von Schultz, p. 242.

70 Paslı, Etkiler, p. 375.

71 Arkan, Yabanc1 Marka, p. 10, fn. 16; Karaman, p. 119; Paslı, Etkiler, p. 375-376, fn. 343; von Schultz, p. 242; Lange, p. 649; Meckel, p. 1; cf. Hacker, p. 613. See Arkan, Yabanc1 Marka, p. 10 regarding the termination of the relation between the parties shall also mean nullification of the authorization granted for the registration of the trademark in the name of the representative; see von Schultz, p. 242-243 regarding that the authorization or consent may have been implicitly revoked depending on the conditions of the actual incident; for example, termination of the relation between the parties or request of the proprietor on assignment of the trademark in his favor may be considered within this scope; similarly see Lange, p. 649.

72 Paslı, Etkiler, p. 375-376, fn. 343; Arkan, Yabanc1 Marka, p. 10; Karaman, p. 119. 
to prove contrary is laid on the applicant ${ }^{73}$. Hence, the representative who requests registration of the trademark in his name must prove that the proprietor has expressly or implicitly granted authorization to such registration ${ }^{74}$.

\section{Representative's Failure to Justify His Actions}

The final common condition required for application of the representative trademark is the representative's failure to justify his action (IPL Art. 10), his inability to base his request for registration of the trademark in his name on a justifiable reason (IPL Art. 6/2).

First of all, it must be pointed out that the "justifiable reason" mentioned hereby is another and a different concept from the "authorization" analyzed above ${ }^{75}$. This means that the "authorization" and "justifiable reason" specified in the provisions regarding the representative trademarks are different terms. Thus for application of the provisions on representative trademarks, it is required both for the proprietor not to grant authorization and for the representative to fail justification of his action to request registration of the trademark in his name ${ }^{76}$.

In the doctrine, there are two opposing views on whether such "justifiable reason" should be "contractual" or not.

From the point of view of Tekinalp, who claims that any justifiable reason in the meaning specified in DLPT Art. 8/2, 11 and 17 (IPL Art. 6/2 and 10) can only be contractual, the representative's need to protect his investment does not justify his action $^{77}$. In this context, the author discusses that the representative's action can be justified if the contract between the proprietor and the representative grants the representative to have the trademark registered in his name ${ }^{78}$.

73 TEG, p. 127.

74 Pasl, Etkiler, p. 375; Fuchs-Wissemann, p. 211. Acting hereon, Pasl states that the authorization must be granted in the beginning during the application for registration and that it should be directly aimed at registration, thus it may always be granted at a contractual platform and in this context, even if there is not an explicit provision in the contract regarding the authorization, if it can be concluded via overall assessment of the contract that registration is required for the representative to use his authorities, exercise his rights and/or fulfill his obligations, it would be accurate to deem that there is an implicit authorization (Pasli, Etkiler, p. 375). Regarding acceptance of the contract provisions other than explicit authorization provisions as implicit authorization provisions also see Paslı, Etkiler, p. 376.

75 Paslı, Etkiler, p. 375, 376.

76 Paslı, Etkiler, p. 375; in this regard also see and cf. Karan/Kılıç, p. 205; Kaya, p. 151; Sekmen, p. 176, fn. 552, p. 177 and Pasli, Etkiler, p. 375.

77 Tekinalp, p. 421; also see Tekinalp, p. 486; for the same view see Çolak, p. 331. In parallel to this view Çolak states that, depending on the relation between the parties, it can be accepted as an example of justifiable reason if the contract regulates that the trademark can be registered by the representative after a certain period of time (Çolak, p. 331). However Tekinalp, following the abovementioned statements, referring to Arkan (Arkan, Marka Vol. I, p. 112), states that acknowledgment that the trademark has not been or will not be extended shall be accepted as justifiable reason and on such assumptions the opposition of the proprietor shall not be justified. Thus the author gives a non-contractual example for justifiable reason (see and cf. Tekinalp, p. 421; in this regard also see Paslı, Etkiler, p. 344). 
The second view which is led by Arkan as far as we have observed and constitutes the majority of the doctrine interprets justifiable reason in a broad sense. Arkan discusses that if the representative introduces the trademark into the market as a result of a long and hard work and gains it reputation, the necessity of effectively protecting such a representative's rights may "justify his action" 79 . This becomes particularly important when the proprietor has explicitly or through his actions indicated that he is no longer interested in the market that the representative carries out his activities ${ }^{80}$. For example this applies when the proprietor does not take any action for extension of the protection period of the trademark he uses for the goods sold in the market that the representative conducts business or waives his trademark right in question and under such assumptions, the proprietor should not be able to oppose the registration of the trademark in the name of the representative ${ }^{81}$. Arkan's abovementioned remarks are also adopted by other authors in the doctrine ${ }^{82}$.

We are also of the opinion that the justifiable reason should not be limited to contractual matters ${ }^{83}$. As accurately identified and expressed in the doctrine, an authorization granted on a contractual degree shall mean that the abovementioned condition of "registration or application for registration being made without authorization of the proprietor" has not been fulfilled. In such case, the provisions of representative trademarks do not apply, because the proprietor has granted

79 Arkan, Marka Vol. I, p. 112; in the same opinion see Noyan/Güneș, p. 158; also see Bauer, p. 250-252 for statements regarding justifiable reason in the meaning of PC Art. $6^{\text {septies }}$ and assessments on comparative law regarding the concept of justifiable reason.

80 Arkan, Marka Vol. I, p. 112; also see Arkan, Yabancı Marka, p. 12-13.

81 Arkan, Marka Vol. I, p. 112; Arkan, Yabanc1 Marka, p. 12-13; in terms of waiver also see TEG, p. 127.

82 Karahan, p. 109; Karan/Kılıç, p. 205; Kaya, p. 151; Paslı, Etkiler, p. 376-377; Sekmen, p. 177; also see Ünal, p. 6465 and Karaman, p. 120-121 who only point out the opposing views in the doctrine. Yasaman points out the opposing views and states that the authorization of the proprietor would not be required on the assumption that he does not take any action to renew the trademark and waives his trademark right, any trademark that is not renewed or is waived can be used by everybody, however the applications for registration of the trademark within two years after the expiration of renewal period shall be rejected upon opposition if the trademark is used by the proprietor within this period (DLPT Art. 8/7, 35/2; IPL Art. 6/8) and it is possible in such case that the opposition of the trademark proprietor that exceeds the application period may not be justified (Yasaman, Vol. I, p. 404; in the same regard see Ünal, p. 65; also see Yasaman/Altay, Vol. II, p. 696; Karaman, p. 123 regarding that it is possible to discuss that the actions are justified when the proprietor waives registration of the trademark in favor of the representative).

However the following must be added regarding the renewal of the trademark: As Pasl righteously emphasizes, nonrenewal of a trademark only and solely must not be acknowledged as intention of the trademark proprietor to waive his trademark right unless supported by additional facts (Paslı, Etkiler, p. 377, fn. 347). This is because expiration of a trademark requires that the protection period to expire and the trademark not to be renewed in due time [IPL Art. 28/1(a)]. The application for renewal must be made by the trademark proprietor within six months before expiration of the protection period and TPTO must be submitted the notification regarding the payment of the renewal fee within the same period. In case the application is not made within such a period and TPTO is not submitted the notification regarding the payment of the renewal fee, the request for renewal can be made through payment of an additional fee within six months following the date of expiration of the protection period (IPL Art. 23/2). Thus the trademark proprietor still has the opportunity to request renewal within a period of six months starting from the expiration of the protection period.

On the other hand, as indicated in the abovementioned statements of Yasaman (again see Yasaman, Vol. I, p. 404), as required by explicit statement of IPL Art. 6/8, an application for registration of a trademark identical or similar to a registered trademark which covers identical or similar goods or services with the registered trademark and is filed within two years following the expiration of the protection of the registered trademark due to non-renewal shall be refused upon opposition of previous trademark proprietor provided that the trademark has been used during this period.

Under such circumstances it is clear that even if in the case of non-renewal, the proprietor still has authority over the trademark; thus only and solely non-renewal of the trademark does not grant the representative the right to apply for registration of the trademark (Pasli, Etkiler, p. 377, fn. 347).

Pasli, Etkiler, p. 376. 
authorization to the representative for registration ${ }^{84}$. Therefore, a justifiable reason cannot be sought. Thus, the terms "justifiable reason" referred in provisions on representative trademarks correspond to the matters which fall outside the contract and arise from the actual status of the relation between the parties and from the approach of the proprietor to the business activities in Turkey ${ }^{85}$.

From this point of view, Pasll states that it may be deemed as an example of justifiable reason if the proprietor explicitly stated that he will not apply for registration in Turkey and in the meantime the representative who made an important investment for the trademark started to be acknowledged as the trademark proprietor in Turkey ${ }^{86}$. The author also discusses that it is also among those examples of justifiable reasons if the proprietor ceases production operations, he explicitly or implicitly waives the trademark due to loss of his interest and profit with the related market and does not concern with the trademark anymore ${ }^{87}$.

Finally it should be pointed out due to their significance, as Pasll accurately identifies and states, those registrations which are made by the representative in order to protect the trademark against any violation by third parties with the aim to transfer the trademark to the proprietor upon his request can be accepted to be based on a justified reason only if the representative duly warns the proprietor about the registration of the trademark but the proprietor does not apply for registration ${ }^{88}$. Thus, in this assumption any registration or application of registration made without fulfillment of the abovementioned conditions shall not be deemed to be based on a justifiable reason.

Likewise, the fact that the representative introduced the trademark to the market and granted it a reputation cannot be deemed as "justifiable reason" alone ${ }^{89}$. A "compensation for clientele" that may be discussed under such assumption is not a matter of trademark law but a matter of contractual law ${ }^{90}$.

\section{Claims Based on the Provisions of Representative Trademarks}

\section{A. Overview}

Following the analysis of the common subjects and exceptional characteristics of the provisions on representative trademarks and the common conditions for

\footnotetext{
84 See Kaya, p. 151 and Paslı, Etkiler, p. 376.

85 Paslı, Etkiler, p. 376. Thus, it is not possible to agree with the following statements in TEG (TEG, p. 127) "The justifiable reason can either arise from the contract (for example, the contract may grant the representative the right to register the trademark in Turkey) ...". Since the proprietor has already granted "authorization" to the representative in such case, the representative does not need to prove justification of his action (Paslı, Etkiler, p. 376, fn. 345).

86 Paslı, Etkiler, p. 376.

87 Paslı, Etkiler, p. 377; in the same regard see von Schultz, p. 243.

88 Pasl, Etkiler, p. 377, fn. 349; cf. Yasaman/Ayoğlu, Vol. I, p. 518-519; Karaman, p. 121.

89 Hacker, p. 614; cf. Arkan, Marka Vol. I, p. 112.

90 Hacker, p. 614. On this regard see TCC Art. 122 and particularly TCC Art. 122/5.
} 
application of such provisions, it is now time to analyze the claims based on the provisions on representative trademarks.

We deem it useful to point out once more, as explained above ${ }^{91}$ and to be repeated again in the following section, that for the proprietor to be able to make claims based on provisions on representative trademarks, it is required for the abovementioned common conditions to be fulfilled, regardless of the claim. Even if only one of the abovementioned conditions are not fulfilled, the proprietor cannot make any claims based on provisions regarding the representative trademarks.

After this short reminder, we may now analyze the claims based on provisions regarding representative trademarks.

\section{B. Being a Relative Ground for Refusal of Application of Registration and a Ground of Invalidity of the Registered Trademark}

The first opportunity granted to the proprietor by the provisions on representative trademarks is to be able to prevent the registration by opposing the application for registration of the trademark in the name of the representative and (IPL Art. 6/2) to demand invalidity of the trademark in case the trademark has already been registered in the name of the representative (IPL Art. 25/1, 6/2). The importance of granting the proprietor the rights to oppose the application during the registration process and to demand invalidity after registration can be explained as follows:

As stated on the title of IPLArt. 6, the grounds regulated by this provision for refusal are "relative". Therefore while it is possible that the registration may be granted if the trademark proprietor does not oppose, the registration may also be granted unlawfully even though the common conditions are fulfilled and the trademark proprietor has opposed the application ${ }^{92}$.

IPL enables the proprietor, who did not or could not prevent the registration before TPTO during registration application, to claim invalidity of the trademark (IPL Art. $25 / 1,6 / 2)^{93}$. Thus, the proprietor is protected even if he did not oppose the registration during application process or his opposition is found unjustified and refused despite fulfillment of the common conditions ${ }^{94}$.

91 See IV, A.

92 Pasli, Etkiler, p. 377; also see Karahan, p. 108.

93 Indeed see Arkan, Yabanc1 Marka, p. 12, 13; also see Arkan, Yabanc1 Marka, p. 13 regarding that the legal actions for invalidity which are based on the provisions on representative trademarks (IPL Art. 25/1 ve 6/2) cannot be prevented even if the trademark registered in the name of the representative has been transferred to another person; see von Schultz, $p$. 242; Hacker, p. 611 who state that MarkenG $\S 11$ regarding invalidity of the representative trademarks shall also apply for the representative's legal successors; see von Zumbusch, p. 427; Fuchs-Wissemann, p. 208-209, 380 for the same opinion regarding the claim for transfer regulated by MarkenG $\S 17 / 1$; for an opposing opinion in terms of a transfer claim see Hacker, p. 835-836. It must be pointed out that von Zumbusch and Fuchs-Wissemann discuss that the claim for prohibition based on MarkenG $\S 17 / 2$ cannot be brought forward againist the representative's legal successors and his licensees (von Zumbusch, p. 428; Fuchs-Wissemann, p. 381).

94 In this assumption the proprietor may also request from the court to transfer the registered trademark in his name (IPL Art. 10; also see Karahan, p. 108). For a detailed explanation about transfer claims of the registered trademark see V, D. 
IPL Art. 6/2 which originates from international trademark law and aims to prevent the representative from taking unfair advantage of the "representative trademark" institution is an exclusive restraint on registration and an exclusive ground for invalidity of a registered trademark (IPL Art. 25/1) ${ }^{95}$. In this context, it is not required that the application of registration or the registration be made in the country where the representative is authorized for application of the provision ${ }^{96}$. The proprietor can oppose the application of registration made in Turkey by the representative ${ }^{97}$

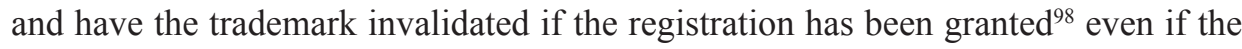
representative's scope of authority does not cover Turkey or the relation between the proprietor and the representative is established in a country out of Paris Union. From the point of view of the example provided in the doctrine: If the Bulgarian representative of the proprietor in France applies for registration of the trademark before TPTO in his own name in Turkey, the proprietor can oppose the application based on Art. 6/299. In such a case the proprietor can either claim invalidity of the trademark if the registration has been granted (IPL Art. 25/1, 6/2) or use any of the rights granted to him by IPL Art. 10 .

To add a final remark, it is not required that the trademark has been used in Turkey by the proprietor or the representative for opposing the application of registration based on IPL Art. 6/2 $2^{100}$. The proprietor can also oppose an application for registration of a trademark which had never been used in Turkey until the application within the framework of IPL Art. 6/2 101 .

\section{Prohibition of Use of the Trademark Registered in the Name of the Representative}

Provided that the common conditions are fulfilled ${ }^{102}$, IPL Art. 10 grants the trademark proprietor the right to demand from the court to prohibit the use of the trademark by the representative despite the registration of the trademark is in the name of the representative ${ }^{103}$. The importance of such right can be explained as follows:

103 In DLPT period, this right was regulated at DLPT Art. 11 which was titled "Prohibition on the Use of Trademark Registered in the Name of an Agent or a Representative" as follows "If a trademark is registered in the name of the agent or representative of the proprietor of the trademark without the proprietor's consent, the proprietor shall be entitled to oppose the use of the trademark unless the agent or representative has a justifiable reason.". IPL uses the terms "prohibition of the use" instead of "oppose the use". Moreover dissimilarly from DLPT Art. 11, IPL Art. 10 does not mention "without the proprietor's consent" (in this regard see and cf. Tekinalp, p. 486; Paslı, Etkiler, p. 381).
} 
Pursuant to the IPL Art. 7/1, the trademark protection provided by IPL is acquired by registration (principle of registration) and the rights arising from a trademark registration shall be granted exclusively to the trademark proprietor (IPL Art. 7/2). The "trademark proprietor" referred hereby and entitled to utilize the protection provided by IPL is "the person in the name of whom the trademark is registered". But as mentioned above ${ }^{104}$, in the assumption which IPL Art. 10 regulates, the proprietor and the formal right owner of a trademark are different persons ${ }^{105}$. This is because the trademark is registered in the name of the representative even though he is not the legal proprietor of the trademark. In order to prevent any problems that may arise in such a case, IPL Art. 10 surrenders the principle of precedence of the formal right owner in appearance to protect the legal proprietor and allows prohibition of use of the registered trademark by the person for whom it has been registered (formal right owner $)^{106}$. However such surrender shall not mean that the proprietor abroad may use any opportunity provided by IPL as if he were the registration holder ${ }^{107}$. IPL Art. 10 is qualified as an exception to the principle of registration and the main rule in acquisition of trademark protection provided by IPL is still IPL Art. $7 / 1^{108}$.

The proprietor shall use his right to prohibition granted by IPL Art. 10 by filing a suit. Such right to prohibition is not limited to the requests of the formal right owner (representative) against the proprietor ${ }^{109}$. Through the lawsuit, the proprietor may prevent the representative from any action concerning the trademark and from using the trademark, despite the registration of the trademark is in the name of the representative ${ }^{110}$. The representative cannot use the registration he holds as a justification for defense and cannot claim requirement of invalidity of the trademark for prohibition of its use ${ }^{111}$.

On the other hand, the proprietor may demand that the court prevents the representative from using his rights arising from the registration of the trademark against himself ${ }^{12}$ and may defend himself based on his actual proprietorship in lawsuits for violation based on misusing or unfair competition filed against himself by the representative ${ }^{113}$. Under such assumption, the case will be dismissed through

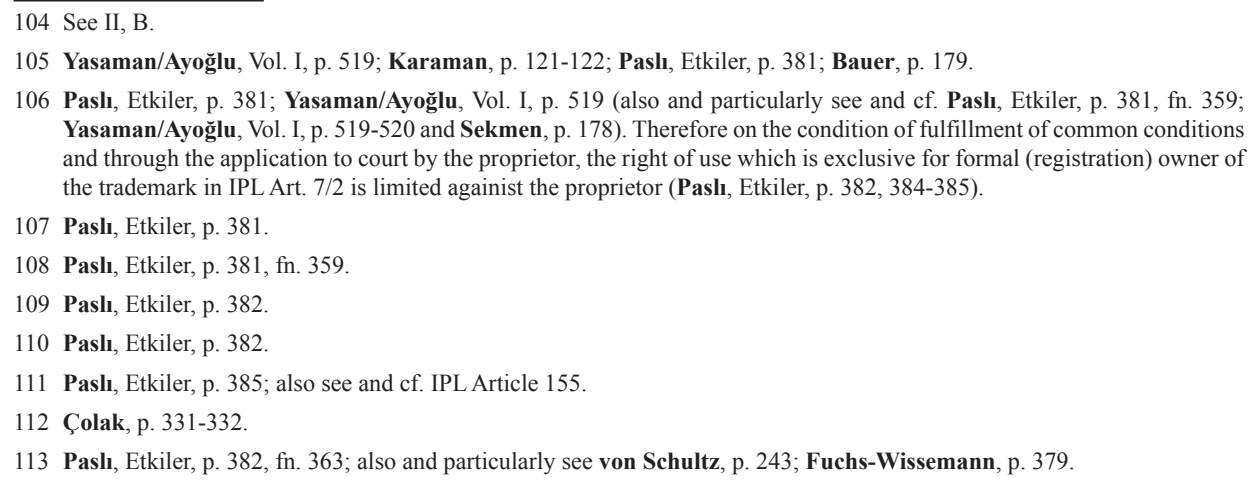


precedence of the proprietor despite the formal right ownership granted by the registration to the representative ${ }^{114}$.

Tekinalp states that it qualifies as a form of interim injunction for the person who is the trademark proprietor by a registration or registrations outside Turkey (legal/ real right owner) to prevent the representative who becomes the formal right owner of the said trademark in Turkey by the registration in Turkey (formal right owner) from using the trademark and that such a lawsuit can be followed by lawsuits for compensation and invalidation and even that the assumption regulated by DLPT Art. 11 (IPL Art. 10) requires opposition right to use of trademark (prohibition right to use of the trademark) to be completed with an invalidation suit and it proves that the invalidation suit is the extension to the opposition (prohibition) right ${ }^{115}$.

The proprietor, indeed, will almost always request from the court not only to prohibit the use but also to transfer the registered trademark to himself (IPL Art. 10) or to invalidate it (IPL Art. 25/1, 6/2). This is so because the claim for prohibition of use applies cumulatively with the claim for transfer (IPL Art. 10) or invalidation (IPL Art. 25/1, 6/2) $)^{116}$. However this does not change the fact that the right of prohibition is independent from the right of invalidation and transfer and those rights can be claimed independently ${ }^{117}$.

We would finally like to point out that while it is indisputable that the right to prohibition regulated by IPL Art. 10 will be used by the "proprietor" through "lawsuits", there is not a consensus in the doctrine regarding the nature of the said lawsuits. While one opinion accepts that the right to prohibition based on IPL Art. 10 (DLPT Art. 11) shall be used through "a claim to prevent and stop the infringement" [DLPT Art. 62/1-(a); IPL Art. 149/1-(b), (c)] ${ }^{118}$, another opinion claims that there is not an exception to the principle of registration here [DLPT Art. 6; IPL Art. 7/1] and the formal right owner holds an exclusive right on action on infringement and the proprietor does not possess a right to be protected by proceedings for infringement and thus he would not be able to file its proceedings for prohibition as a lawsuit for infringement and that he would be able to use the right to protection granted by IPL Art. 10 within the scope of general protection rules based on unfair competition within the framework of the TCC Art. 54 ff. provisions ${ }^{119}$. The second opinion also

114 Paslı, Etkiler, p. 382, fn. 363.

115 Tekinalp, p. 485; in the same opinion see Çağlar, p. 143.

116 Pasl, Etkiler, p. 382, fn. 362. However a cumulative application is not possible in terms of claims for "invalidation" (IPL Art. 25/1, 6/2) and "transfer" (IPL Art. 10) (see and cf. V, D).

117 See Paslı, Etkiler, p. 382 regarding independency of the right of prohibition from the claim for invalidation; also see Berlit, p. 221-222.

118 In this opinion see Arkan, Yabancı Marka, p. 14 and particularly Arkan, Yabancı Marka, p. 14, fn. 31; Tekinalp, p. 421, 449, 485; Karan/Kılıç, p. 282; Sekmen, p. 178.

119 Paslı, Etkiler, p. 383-385. The author states that TCC Art. 56/1-(b) and (c) provides the proprietor with the opportunity to prevent the formal right owner from using the trademark and to eliminate the factual circumstances incurred and 
mentions that there must be an explicit provision of law which provides for a person who is not a registration holder to be qualified as a plaintiff in terms of claiming requests granted to the holders of registered trademarks ${ }^{120}$.

However regardless of whichever point of view is adopted, there is no dispute that the proprietor can prevent the representative who becomes the formal right owner of the trademark from performing the following based on IPL Art. 10: From affixing the sign to the goods or to the packaging thereof [IPL Art. 7/3-(a)], putting the goods on the market, offering them as deliverable or stocking them for these purposes under the trademark or offering or supplying services under the trademark [IPL Art. 7/3(b)], importing or exporting the goods under the trademark [IPL Art. 7/3-(c)], using the trademark on business papers and advertisements [IPL Art. 7/3-(ç)], using the trademark on internet as domain name, router code, keyword or in similar manner with a commercial impression [IPL Art. 7/3-(d)] and using the sign as a business name or a trade name [IPL Art. 7/3-(e)]. Therefore whether based on IPL Art. 149/1(b), (c) or TCC Art. 54 ff. (and TCC Art. 56 in particular) provisions, the proprietor can without a doubt prevent the representative from carrying out any of the actions specified in IPL Art. 7/3-(a), (b), (c), (ç), (d) and (e). We are of the opinion that the fact that IPL is not regulated to contain a similar reference in MarkenG $\S 17 / 2$ to MarkenG $\S 14$ in German law, meaning that IPL Art. 10 does not include a reference to IPL Art. 7, does not prevent such conclusion. The scope of provisions of TCC Art. 56/1-(b), (c) and TCC Art. 61 already prevent the representative from carrying out the actions specified in IPL Art. 7/3-(a), (b), (c), (ç), (d) and (e) ${ }^{121}$.

\section{Claim the Transfer of the Registered Trademark}

Upon fulfillment of the common conditions ${ }^{122}$, another opportunity granted by IPL to the proprietor of the trademark is to request that the court transfers the registration to himself ${ }^{123}$ (IPL Art. 10). This grants the trademark proprietor who has not or could not prevent the registration based on IPL Art. 6/2 the right to be registered as the trademark proprietor instead of "his representative" through a lawsuit based on IPL Art. 10 while the record of the trademark in the registration remains the same, instead of claiming invalidation of the registered trademark ${ }^{124}$. This provides

furthermore discusses that it is possible for the proprietor of the trademark to claim compensation (pecuniary and nonpecuniary) specified in TCC Art. 56/1-(d) and (e) and even though it may be considered that the provisions of PC and IPL (PC Art. $6^{\text {septies; }}$ IPL Art. 10) provides the proprietor with only the opportunity of protection, there is categorically not a reason that requires refusal of the claim of compensation on the ground that the protection granted by the registration will not be available (Pasli, Etkiler, p. 385-386, fn. 372).

120 Paslı, Etkiler, p. 385, fn. 369.

121 On this subject also see and cf. Paslı, Etkiler, p. 382 and Paslı, Etkiler, p. 383, fn. 365.

122 See IV.

123 While "transfer of the registration" is mentioned hereby, the subject of the transfer is in fact "the trademark right granted by the registration" (indeed see Sabih Arkan, Marka Hukuku, Vol. II, Ankara 1998, p. 160).

124 Paslı, Etkiler, p. 378-379. 
the trademark proprietor with an alternative to the invalidation claim ${ }^{125}$. The most important advantage of the possibility of transfer is that the proprietor will acquire the trademark right in Turkey with the precedence granted by the registration in the name of the representative ${ }^{126}$.

The conditions for application of invalidation of the representative trademark based on IPL Art. 25/1 and 6/2 and claiming its transfer pursuant to IPL Art. 10 are common $^{127}$. In this context, the terms "justifiable reason" mentioned in IPL Art. 6/2 and IPL Art. 10 are also not different ${ }^{128}$. Thus we would like to repeat once more that the abovementioned common conditions shall be sought for transfer of the trademark registered in the name of the representative, as well.

Contrary to DLPT Art. 17, IPL Art. 10 expressly specifies that the transfer of the trademark may be requested from "the court" ${ }^{\prime 29}$. It is undisputable that the trademark proprietor may request that the representative transfers the trademark in his favor before filing a suit. If the representative accepts such a request and transfers the trademark to its proprietor, the problem will be solved. However if the representative avoids the transfer, the proprietor is required to file a lawsuit based on IPL Art. 10 in order to take over the trademark. The proprietor cannot have the trademark transferred to himself by submitting his request of transfer to TPTO and TPTO is not authorized to order such a transfer.

Only the proprietor of the trademark may file a lawsuit for transfer of the trademark based on IPL Art. $10^{130}$. Pursuant to the explicit provision of IPL Art. 10, the plaintiff may request transfer of the trademark solely "to himself". The trademark cannot be requested to be transferred to a third party appointed by the plaintiff ${ }^{131}$. The doctrine also accepts requests for transfer in part for the goods and/or services covered by the trademark based on the permissibility that registration is possible for different goods and/or services of the same trademark ${ }^{132}$.

125 Paslı, Etkiler, p. 378; Hacker, p. 835; Fuchs-Wissemann, p. 207.

126 von Zumbusch, p. 426; also see Hacker, p. 608, 835, 836; Fuchs-Wissemann, p. 379. See Arkan, Yabanc1 Marka, p. 13; Karaman, p. 123 regarding that the opportunity for the transfer is accepted considering that the invalidation may not always suffice to protect the interests of the proprietor and that the proprietor may deem it more advantageous in terms of his interests to acquire the trademark right in Turkey with the precedence granted by the registration in the name of the representative.

127 Paslı, Etkiler, p. 379; also see Arkan, Yabancı Marka, p. 13; Paslı, Etkiler, p. 379, fn. 353 ; Hacker, p. 835.

128 The doctrine explicitly stated during DLPT period that although different in expression, "valid justification" in DLPT Art. 8/2 and "justified reason" DLPT Art. 17 are the same in context (see Paslı, Etkiler, p. 379).

129 DLPT Art. 17 was not clear on request of transfer to be made through a lawsuit. However the doctrine accepted also during DLPT period that the request was to be made through filing a lawsuit since TPI (TPTO) is not authorized to make judgements on justifiability. Indeed see Tekinalp, p. 465; Yasaman/Altay, Vol. II, p. 696; Karaman, p. 123; Karan/Kılıç, p. 338; Paslı, Etkiler, p. 379-380.

130 Paslı, Etkiler, p. 380.

131 Pasl, Etkiler, p. 380. However the proprietor who has the trademark transferred to himself after succeeding in the lawsuit could initiate legal transactions within the scope of IPL Art. 148 regarding his registered trademark (such as transferring it to a third party of choice) (Pasl, Etkiler, p. 380).

132 Arkan, Yabancı Marka, p. 13; Karaman, p. 123; Paslı, Etkiler, p. 380; also see Hacker, p. 835; von Zumbusch, p. 426; 
The transfer regulated by IPL Art. 10 is a "compulsory" transfer for which the consent of the transferor (the "representative" who is the formal rightful owner of the registered trademark) is not sought ${ }^{133}$. It is also not required for the representative to have acted negligently regarding trademark registration for the proprietor to use IPL Art. 10 as a basis for transfer ${ }^{134}$. Therefore if the common conditions are fulfilled and the trademark proprietor requests "transfer" within the framework of IPL Art. 10 , the court shall decide on transfer of the trademark to its legal proprietor without the consent of the representative and even contrary to his will ${ }^{135}$. From this point of view, the doctrine deems the right of the trademark proprietor to request the transfer of the trademark to himself as a "formative right (=right to alter the legal relationship unilaterally) exercised via litigation" ${ }^{\prime 36}$.

On the other hand, it shall be pointed out that even though the conditions for claims based on representative trademarks are common, cumulative application in terms of claims of "invalidation" (IPL Art. 25/1, 6/2) and "transfer" (IPL Art. 10) is out of the question ${ }^{137}$. This means that an "invalidation of the trademark" and "transfer" cannot be requested from the court at the same time. The trademark proprietor must choose either one of these two ${ }^{138}$. If the trademark proprietor claims requests of invalidation and transfer through alternative pleading (CPL Art. 111), the court shall evaluate the principal request in the first place. In alternative pleading, the court may not evaluate and adjudicate the secondary claims of the plaintiff without dismissing the principal claim (CPL Art. 111/2). Therefore the principal claim of the trademark proprietor is significant. For example if the trademark proprietor has principally requested invalidation and the required conditions are fulfilled (IPL Art. 25/1, 6/2), the court shall give a ruling for invalidation and it shall not evaluate the request for transfer and shall not be able to rule in terms of such a request ${ }^{139}$. On the assumption that the principal request is a transfer (IPL Art. 10) and the secondary request is invalidation (IPL Art. 25/1, 6/2) in alternative pleading, the request for transfer shall be evaluated in the first place and the secondary request of invalidation shall be evaluated in case of dismissal of the transfer request ${ }^{140}$.

Fuchs-Wissemann, p. 379.

133 Tekinalp, p. 465.

134 Arkan, Yabanc1 Marka, p. 13; Karaman, p. 123; Paslı, Etkiler, p. 379, fn. 353; Hacker, p. 835; Fuchs-Wissemann, p. 379.

135 In this context, the property of the trademark shall be transferred to the proprietor based on the decision of the court on the transfer and after entry of the judgment into force, the adjustment of the record in the trademark registry shall only have a declarative effect (Paslı, Etkiler, p. 380).

136 Yasaman/Altay, Vol. II, p. 696; Karaman, p. 123; Paslı, Etkiler, p. 379-380.

137 Pasli, Etkiler, p. 379.

138 PC Art. $6^{\text {septies }}$ also indicates that the proprietor must choose between "invalidation" and "transfer" (Pasl,, Etkiler, p. 379).

139 Çolak, p. 909. We must add that the author is on the opinion that it shall be better to claim it as a principal request if invalidation shall be requested (Çolak, p. 909-910).

140 For an example case on this possibility see Decision of the $11^{\text {th }}$ Chamber of the Court of Cassation dated 21.03.2014 and numbered 2012-16334/5593 (Çolak, p. 910-911); also see and cf. Decision of the $11^{\text {th }}$ Chamber of the Court of Cassation dated 04.04.2011 and numbered 2009-9836/3827 (Çolak, p. 910). 
Since the conditions for a request of invalidation based on IPL Art. 25/1 and 6/2 and a request for transfer based on IPL Art. 10 are common, the court shall be obliged to recognize whichever is the principal request of the plaintiff in case of fulfillment of such common conditions. From this point of view, if the plaintiff has explicitly requested invalidation within the framework of IPL Art. 25/1 and 6/2 and requested transfer as a secondary claim based on IPL Art. 10, the court cannot give precedence to the request of transfer ${ }^{141}$. If the conditions required by IPL Art. 25/1 and 6/2 are fulfilled -which are identical to the conditions required by IPL Art. 10- the court shall be obliged to recognize the proprietor's principal request for invalidation and give a ruling for invalidation of the trademark. Without prejudice to the provisions of law that provides for otherwise (CPL Art. 26/2), the judge is bound by the requests of the parties. Although he can decide less than the request, he may not rule on more or other than requested by the parties (CPL Art. 26/1). This rule is called "the principle of being bound by the request (=ultra petita prohibition)".

If the proprietor insists on alternative pleading, we are of the opinion that he should claim the request of transfer, which shall be in his favor under any circumstances, as the principal request and claim the request on invalidation as the secondary request. IPL Art. 10 is not only more advantageous for the proprietor since it relieves the burden of re-applying for registration before TPTO after invalidation and deletion of the registered trademark by granting the right to the property of an already existing registration and protects the proprietor against the risk of registration by third parties during the interim period but it also serves to the procedural economy in terms of trademark registration system by relieving the TPTO of the burden of monitoring a new registration procedure for the same trademark ${ }^{142}$.

In order for the trademark to be transferred to the trademark proprietor based on IPL Art. 10, the trademark must be registered in TPTO trademark registry ${ }^{143}$. Thus if the trademark right shall end since the representative - who is also the formal right owner - does not renew the trademark despite expiry of the protection period [IPL Art. 28/1-(a)] or waives his trademark right [IPL Art. 28/1-(b)] and the trademark is deleted from the registry during the lawsuit filed on the request of transfer, the court cannot decide transfer of such a trademark anymore ${ }^{144}$.

A decision of transfer made based on IPL Art. 10 - just as in the decision for invalidation (IPL Art. 27) - retroactively confirms the property and after finalization of the decision, no claims of any restrictive rights such as licensing or pledging can be

141 However see and cf. Çolak, p. 910.

142 Pasli, Etkiler, p. 379, fn. 352.

143 Çolak, p. 911.

144 Çolak, p. 911; also see Decision of the $11^{\text {th }}$ Chamber of the Court of Cassation dated 22.09.2014 and numbered 12345/14249 (Çolak, p. 911). 
raised against the proprietor of the trademark ${ }^{145}$. However there is no doubt that those who have concluded a licensing or pledge agreement with the representative during the period of registration of the trademark in his name, shall be able to claim damages from the representative if the conditions thereof are fulfilled ${ }^{146}$.

\section{Time-Dependency of Requests and Registration in Bad Faith}

PC Art. $6^{\text {septies }} 3$ specifies "Domestic legislation may provide an equitable time limit within which the proprietor of a mark must exercise the rights provided for in this Article.". However Turkey did not utilize the opportunity of PC Art. $6^{\text {septies }} / 3$ that covers all claims based on representative trademarks and enables the determination of a period in terms of the said claims during DLPT period ${ }^{147}$ and it also did not utilize such an opportunity in IPL neither. In other words, it does not provide for a time limit for exercising the rights regulated by the provisions of IPL regarding representative trademarks. However the fact that there is not a time limit specified in IPL in terms of exercising the rights granted by the provisions on representative trademarks shall not mean that the abovementioned rights can be used indefinitely ${ }^{148}$. On the contrary, the time limits in the Turkish legislation apply to the legal means based on which each claim in the provisions on representative trademarks ${ }^{149}$. Therefore the period of three months specified in IPL Art. 41/1 shall apply for opposing the application of a registration based on IPL Art. $6 / 2^{150}$. In terms of any claim for invalidation of IPL Art. 6/2 (IPL Art. 25/1), the period of prescription of five years specified in IPL Art. $25 / 6$ shall apply ${ }^{151}$. Since the transfer claim is qualified as an alternative to the invalidation claim, the abovementioned period of five years will also apply for the claim of transfer regulated in IPL Art. $10^{152}$.

However it must be emphasized that the five years period of prescription does not apply to the registrations in bad faith pursuant to the explicit provision in IPL Art. 25/6. This means that the lawsuit for invalidation is not subject to any specified period in case of registration in bad faith. Hence, if the representative has registered the trademark in bad faith, the lawsuits for invalidation (IPL Art. 25/1, 6/2) and transfer of the trademark (IPL Art. 10) -which is the alternative to invalidation- can be filed without being subject to a period of prescription.

\footnotetext{
145 Pasli, Etkiler, p. 380; also see von Zumbusch, p. 427-428; Fuchs-Wissemann, p. 379-380. This is caused due to the absence of a regulation for protection of confidence in the trademark registry in IPL regarding the said issues, just like it was in DLPT (see Paslı, Etkiler, p. 380 and also see Arkan, Marka Vol. II, p. 183-184; Arkan, Yabancı Marka, p. 13; Karaman, p. 123 mentioned on Paslı, Etkiler, p. 380, fn. 358). On this subject also see and cf. Hacker, p. 836.

146 On this subject also see and cf. IPL Art. 27/3-4.

147 Arkan, Yabancı Marka, p. 13; Karaman, p. 124; Paslı, Etkiler, p. 386.

148 Pasl, Etkiler, p. 386.

149 Paslı, Etkiler, p. 386.

150 Paslı, Etkiler, p. 386.

151 Regarding DLPT period see Pasl, Etkiler, p. 386-387.

152 Paslı, Etkiler, p. 387.
} 
Let's point out that: It is not possible to say that all of the registered representative trademarks are categorically classified as registrations in bad faith. It is indisputable that the representative may have attempted for registration in bad faith by abusing his position and knowledge acquired in parallel to his authorization to use the trademark $^{153}$ or by violating his obligation of loyalty ${ }^{154}$. It is also indeed a fact that such attempts are observed often. However such fact shall not mean that all registered representative trademarks are registrations in bad faith ${ }^{155}$. Just as in every other trademark registration, each registration for a representative trademark shall be evaluated and determined in terms of registration in bad faith based on the particular conditions of each incident ${ }^{156}$.

A distinction is required for the lapse of time to which the authorization of "prohibition" based on IPL Art. 10 is subject to. As analyzed above ${ }^{157}$, the legal nature of the lawsuit regarding use of such authorization is controversial in the doctrine. Based on such, if the right of prohibition regulated by IPL Art. 10 (DLPT Art. 11) is assumed to be used via "a claim to prevent and stop the infringement" [DLPT Art. 62/1-(a); IPL Art. 149/1-(b), (c)], due to the reference to TCO in IPL Art. 157, the lapse of time of two and ten years regulated in TCO Art. 72/1 shall apply. However if the right of prohibition based on IPL Art. 10 is assumed to be used within the scope of general protection rules based on unfair competition within the framework of TCC Art. $54 \mathrm{ff}$., then a lapse of time of one and three years regulated by TCC Art. 60 shall apply ${ }^{158}$. Nevertheless, regardless of the opinion adopted, without prejudice to TCiC Art. 2, the lapse of time shall restart regarding the request of prohibition with each means of the use of the trademark ${ }^{159}$.

The final remark we would like to add is that if a registration in bad faith is out of the question and the five year period of prescription provided for in IPL Art. 25/6 has expired, the proprietor cannot claim invalidation of the trademark based on IPL Art. 6/2 or transfer of the trademark to himself based on IPL Art. 10. Thus, after expiry of the five year period, the use by the representative of the trademark cannot

153 Paslı, Etkiler, p. 366 .

154 Tekinalp, p. 421, 486

155 See and cf. Arkan, Yabancı Marka, p. 13; Karaman, p. 124 who discuss that it may be considered that the representative will never act in good faith due to the absence of a specific time period for exercising the rights regulated by the representative trademarks provisions.

156 On this subject also see and cf. Paslı, Etkiler, p. 368-370, fn. 331 and p. 386-387; Çolak, p. 332, 909, 1039-1040; Noyan/ Güneş, p. 158; Decision of the $11^{\text {th }}$ Chamber of the Court of Cassation dated 17.04.2014 and numbered 111/7636 (Çolak, p. 332); Decision of the $11^{\text {th }}$ Chamber of the Court of Cassation dated 01.06.2009 and numbered 2008-2952/6682 (Çolak, p. 332); Decision of the $11^{\text {th }}$ Chamber of the Court of Cassation dated 25.06.2009 and numbered 2008-3616/7841 (Çolak, p. 332); Decision of the $11^{\text {th }}$ Chamber of the Court of Cassation dated 26.09.2006 and numbered 2005-8389/9281 (Çolak, p. 333); Decision of the $11^{\text {th }}$ Chamber of the Court of Cassation dated 11.10.2012 and numbered 2011-8375/15830 (Çolak, p. 333); Decision of the $11^{\text {th }}$ Chamber of the Court of Cassation dated 23.11.2007 and numbered 2006-7640/14803 (Noyan/ Güneș, p. 159).

157 See V, C.

158 Paslı, Etkiler, p. 387.

159 Paslı, Etkiler, p. 387, fn. 376; on this regard also see Çolak, p. 827-828. 
be prohibited within the scope of IPL Art. 10. This means that the proprietor cannot have the use of a trademark prohibited if he cannot request invalidation based on IPL Art. 6/2 or transfer hereof to himself based on IPL Art. 10 due to the expiry of the period of prescription in IPL Art. 25/6. The use of the registered trademark by the representative cannot be prohibited on the grounds of IPL Art. 10 after this point.

\section{Conclusion}

1. IPL Art. $6 / 2,10$ and $25 / 1$ are the provisions regarding representative trademarks. These IPL provisions are based on PC Art. $6^{\text {septies }}$ regulations.

2. If the common conditions are fulfilled, the provisions regarding representative trademarks grant the following rights to the proprietor: To ensure rejection of the application and prevention of the registration by opposing the application for the registration of the trademark in the name of the representative (IPL Art. 6/2), to claim invalidation of the trademark if the trademark has been registered in the name of the representative (IPL Art. 25/1, 6/2), to claim transfer of the registration (trademark) to himself, also on the assumption that the trademark has been registered in the name of the representative (IPL Art. 10) and to request prohibition of the use of the trademark registered in the name of the representative (despite the registration) (IPL Art. 10).

3. "The trademark proprietor" referred to in IPL Art. $6 / 2$ and 10 is the legal/real right owner of the mark (trademark) which the representative has registered or has applied for registration before TPTO. In such case, if the representative has acquired the registration of the trademark in his name before TPTO, the proprietor and the formal right owner of the trademark become different.

4. It must be noted that to exercise the provisions of IPL regarding representative trademarks (IPL Art. 6/2,10,25/1), the trademark proprietor and the person who has registered or applied for registration of the trademark in his name before TPTO must have a relationship which concerns the use of the trademark, distribution of the goods branded with the trademark or delivery of service or services under such trademark. The relationship between the proprietor and the person who wants to register or has registered the trademark in his name is defined as "commercial agency" or "commercial representation" in IPL.

5. The terms "commercial agent or representative" used in the provisions on representative trademarks shall not be limited to the commercial agent or (commercial) representative in the technical legal meaning specified in TCO Art. $547 \mathrm{ff}$. but shall be interpreted in a broad sense and any person who is authorized to use the trademark in Turkey (for example to sell the goods branded with the trademark or provide service or services under the trademark on behalf of the proprietor or himself) based on a 
continuous and affiliated relationship pursuant to any attorney contract, exclusive distributorship agreement, labor contract, license agreement, franchise agreement, agency contract, brokerage contract, distributorship or dealership agreement shall be deemed as "representative" in terms of exercise of IPL Art. 6/2 and 10, whether or not granted the power to represent the proprietor in technical legal meaning.

6. There are three exceptional characteristics of the provisions on representative trademarks. These are: (i) precedence of the legal/real right owner (proprietor) over the formal right owner which is an exception to the principle of registration (IPL Art. 10; DLPT Art. 11), (ii) ability to transfer the trademark though court decision (IPL Art. 10; DLPT Art. 17) and (iii) being provided for as an exception to the principle of territoriality (IPL Art. 6/2; DLPT Art. 8/2).

7. The provisions on representative trademarks protect a common interest and aim to prevent any problem that may be caused by the proprietor and formal right owner being different parties. In parallel with the same interest they share, the conditions of application of the provisions on representative trademarks are common.

8. The provisions on representative trademarks apply to both the service marks and the trade marks. It is not required for the trademark to be well-known for the proprietor to exercise the protection granted by the provisions on representative trademarks.

9. Even if the conditions of application of the provisions on representative trademarks are common, the authority to exercise such provisions is not always the same. If there is a registered trademark, the requests for prohibition and transfer of this trademark (IPL Art. 10) or its invalidity (IPL Art. 25/1, 6/2) shall be sent to the court. However if there is an application for registration (IPL Art. 6/2), the proprietor opposes the application before TPTO and TPTO shall be the authority to make a decision about the opposition in question.

10. It must be accepted that the protection granted by the provisions regarding representative trademarks - despite the strict sense in their wording - is to the extent specified in IPL Art. 6/1. These provisions can be applied when the trademark subject to the application of registration by the representative is identical or similar in terms of both the sign and the goods or services of the trademark of the proprietor. If a trademark applied for registration or already registered in the name of the representative before TPTO is identical or similar to the trademark of the proprietor in terms of both the sign and the goods or services and if this situation causes a likelihood of confusion - including the relation possibility by the public - between them (IPL Art. 6/1), the provisions of the representative trademarks (IPL Art. 6/2, $10,25 / 1)$ may apply. This is the first common condition required for application 
of the provisions on representative trademarks. Therefore, the proprietor has the opportunities to oppose the registration application before TPTO (IPL Art. 6/2), to request prohibition of use or assignment in his favor of the trademark registered by such means (IPL Art. 10) or to claim invalidity of the trademark (IPL Art. 25/1, 6/2) if it causes a likelihood of confusion - including the relation possibility by the public - with his trademark because of the identity or similarity of the signs and identity or similarity of the goods or services that it covers.

11. The second common condition required for application of the provisions on representative trademarks is making application of registration or registration of the trademark without the authorization (consent) of the proprietor. The "authorization" mentioned hereby is "for registration of the trademark in the name of the representative before TPTO", meaning the authorization "for registration". Such condition is also fulfilled, if the proprietor approves the registration in the name of the representative later, even if it had not been requested permission from him in the first place. The registration now becomes subject to consent and "authorized" within the meaning in IPL Art. 6/2 and 10. The authorization or consent specified in IPL Art. 6/2 and 10 is not subject to any form requirement. It can also be "implied (implicit)" in such terms.

12. The final common condition required for application of the representative trademark is representative's failure to justify his action (IPL Art. 10), his inability to base his request for registration of the trademark in his name on a justifiable reason (IPL Art. 6/2). It must be pointed out that the "justifiable reason" mentioned hereby is another and a different concept from the "authorization" analyzed above. This means that the "authorization" and "justifiable reason" specified in the provisions regarding the representative trademarks are different terms. Thus for application of the provisions on representative trademarks, it is both required for the proprietor not to grant authorization and for the representative to fail justification of his action to request registration of the trademark in his name. In the doctrine there are two opposing views on whether such "justifiable reason" should be "contractual" or not. We are of the opinion that the "justifiable reason" should not be limited to contractual facts.

13. The first opportunity granted to the proprietor by the provisions on representative trademarks is to be able to prevent the registration by opposing the application for registration of the trademark in the name of the representative and (IPL Art. 6/2) to demand invalidity of the trademark in case the trademark has already been registered in the name of the representative (IPL Art. 25/1, 6/2). IPL enables the proprietor who did not or could not prevent the registration before TPTO during registration application to claim invalidity of the trademark (IPL Art. 25/1, 6/2). The proprietor 
is protected even if he did not oppose the registration during the application process or his opposition is found unjustified and refused despite fulfillment of the common conditions.

14. IPL Art. 10 grants the trademark proprietor the right to demand from the court to prohibit the use of the trademark by the representative despite the registration of the trademark is in the name of the representative. This provision surrenders the principle of precedence of the formal right owner in appearance to protect the legal proprietor and allows prohibition of use of the registered trademark by the person for whom it has been registered (formal right owner).

15. Another opportunity granted by IPL to the proprietor of the trademark is to request from the court to transfer the registration to himself (IPL Art. 10). This provides the trademark proprietor with an alternative to the invalidation claim. The most important advantage of the possibility of transfer is that the proprietor will acquire the trademark right in Turkey with the precedence granted by the registration in the name of the representative. The transfer regulated by IPL Art. 10 is a "compulsory" transfer for which the consent of the transferor (the "representative" who is the formal right owner of the registered trademark) is not sought. From this point of view, the doctrine deems the right of the trademark proprietor to request the transfer of the trademark to himself as a "formative right exercised via litigation".

16. Turkey does not provide for a time limit for exercising the rights regulated by the provisions of IPL regarding representative trademarks. However the fact that there is not a time limit specified in IPL in terms of exercising of the rights granted by the provisions on representative trademarks shall not mean that the abovementioned rights can be used indefinitely. On the contrary, the time limits in the Turkish legislation for the legal means that these rights are based on applying to each claim in the provisions on representative trademarks.

Grant Support: The author received no grant support for this work. 


\section{List of Abbreviations}

Art. : Article

cf. : confer (compare)

CPL : Civil Procedure Law Nr. 6100

DLPT : Decree-Law (Nr. 556) on the Protection of Trademarks

ff. $\quad$ : and the following

fn. : footnote

IPL : Industrial Property Law Nr. 6769

MarkenG : Gesetz über den Schutz von Marken und sonstigen Kennzeichen (Law on the Protection of Trademarks and Other Hallmarks)

n.d. : no date

Nr. : number

OLG : Oberlandesgericht (Higher Regional Court)

p. : page

passim : throughout

PC : Paris Convention for the Protection of Industrial Property

pp. : : pages

TCC : Turkish Commercial Code Nr. 6102

TCiC : Turkish Civil Code Nr. 4721

TCO : Turkish Code of Obligations Nr. 6098

TPI : Turkish Patent Institute

TPTO : Turkish Patent and Trademark Office (TURKPATENT)

Vol. : volume 


\section{Bibliography}

Arkan, Sabih: "Yabanc1 Markaların Türkiye'de Korunması", Banka ve Ticaret Hukuku Dergisi, Vol. XX, Nr. 1, 1999, pp. 5-17 (Yabanc1 Marka).

Arkan, Sabih: Marka Hukuku, Vol. I, Ankara 1997 (Marka Vol. I).

Arkan, Sabih: Marka Hukuku, Vol. II, Ankara 1998 (Marka Vol. II).

Bauer, Florian: Die Agentenmarke Rechtsfragen des internationalen Vertriebs von Markenwaren, Schriftenreihe zum gewerblichen Rechtsschutz Vol. 27, Köln Berlin Bonn München 1972.

Berlit, Wolfgang: Markenrecht, 11. Edition, München 2019.

Çağlar, Hayrettin: Marka Hukuku Temel Esaslar, 2. Edition, Ankara 2015.

Çolak, Uğur: Türk Marka Hukuku, 4. Edition, İstanbul 2018.

Fuchs-Wissemann, Georg and others: Markenrecht Vol. I Markengesetz und Markenrecht ausgewählter ausländischer Staaten, 2. Edition, Heidelberg 2009.

Karahan, Sami: Marka Hukukunda Hükümsüzlük Davaları, Konya n.d.

Karaman, Fatma: Marka Hukukunda Markanın Ülkeselliği İlkesi, Unpublished Master's Thesis, Marmara University Institute of Social Sciences Department Of Law Sub Department of Private Law, İstanbul 2008.

Karan, Hakan/Kılı̧̧, Mehmet: Markaların Korunması 556 Sayılı KHK Şerhi ve İlgili Mevzuat, Ankara 2004.

Kaya, Arslan: Marka Hukuku, İstanbul 2006.

Lange, Paul: Marken- und Kennzeichenrecht, München 2006.

Noyan, Erdal/Güneş, İlhami: Marka Hukuku, 5. Edition, Ankara 2015.

Pasl, Ali: Marka Hukukunda Ürün Benzerliği, İstanbul 2018.

Paslı, Ali: Uluslararası Antlaşmaların Türk Marka Hukukunun Esasına İlişkin Etkileri, İstanbul 2014 (Etkiler).

Sekmen, Orhan: Markanın Hükümsüzlüğü ve Hukuki Sonuçları, 2. Edition, Ankara 2016.

Ströbele, Paul/Hacker, Franz/Kirschneck, Irmgard: Markengesetz Kommentar, 8. Edition, Köln Berlin München 2006.

Tekinalp, Ünal: Fikrî Mülkiyet Hukuku, 5. Edition, İstanbul 2012.

Ünal, Alper Tunga: Marka Hukukunda Tescil Engelleri, Unpublished Master's Thesis, Gazi University Institute of Social Sciences Department of Private Law, Ankara 2007.

Uzunallı, Sevilay: "Marka Hukukunda Malların ve/veya Hizmetlerin Benzerliğinin Tespiti Sorunu”, Prof. Dr. Hamdi Yasaman'a Armağan, İstanbul 2017, pp. 675-699.

von Schultz, Detlef/von Zumbusch, Ludwig and others: Kommentar zum Markenrecht, 2. Edition, Frankfurt am Main 2007.

Yasaman, Hamdi/Altay, Sıtkı Anlam/Ayoğlu, Tolga/Yusufoğlu, Fülürya/Yüksel, Sinan: Marka Hukuku 556 Sayılı KHK Şerhi, Vol. I, İstanbul 2004 (Vol. I).

Yasaman, Hamdi/Altay, Sıtkı Anlam/Ayoğlu, Tolga/Yusufoğlu, Fülürya/Yüksel, Sinan: Marka Hukuku 556 Sayı1ı KHK Şerhi, Vol. II, İstanbul 2004 (Vol. II). 


\section{Online Sources}

Meckel, Astrid: “Agentenmarke”, <https://wirtschaftslexikon.gabler.de/definition/agentenmarke31838/version-255389>, accessed on 17 July 2019.

Turkish Patent and Trademark Office Trademark Examination Guidelines 2015, <https:// www.turkpatent.gov.tr/TURKPATENT/resources/temp/F9E4CFAF-A7AE-4FEA-8BCCDA8B5C7DAB00.pdf $>$, accessed on 5 July 2019 (TEG). 
